\title{
Livestock research generated technologies and their impact on Bangladesh national economy
}

\author{
F. Yasmin ${ }^{1 *}$ and S. M. K. Alam ${ }^{2}$ \\ ${ }^{1}$ Technology Transfer Division and ${ }^{2}$ Crops Division, Bangladesh Agricultural Reasearch Council, \\ Farmgate, Dhaka, Bangladesh
}

\begin{abstract}
This study was conducted by using annual research investment data of BLRI to estimate the impact of livestock research generated technologies on national economy of Bangladesh. The results showed that the livestock research investment was increased and consequently contribution in GDP of livestock sector was also increased. The result of Chow Test $\mathrm{F}_{1,35}=4.35$ indicated that there is a great positive impact of livestock technologies on livestock Gross Domestic Product (GDP). The results revealed that the contribution of generated livestock technologies through annual investment Tk.1.65 million in livestock research, which was increased livestock GDP by Tk. 3,044.56 million annually which saved Tk. 2913.93 million of import expenditures of livestock products from outside countries. Therefore, to save significant amounts of foreign exchange through reducing imports and earn more foreign exchange through export; more investment on livestock research is needed. Hence, further national economic development, Bangladesh government must emphasize research investment for generating livestock technologies.
\end{abstract}

(Keywords: Livestock research investment, Livestock technologies, Livestock GDP.)

\section{Introduction}

Bangladesh is predominately an agricultural country. Eighty percent $(80 \%)$ of the rural people depend on agriculture and livestock plays an important role by producing livestock products. The demand for livestock products in Bangladesh is increasing due to the increasing number of human population. The production of livestock products is not sufficient to meet the demand. The production of meat, milk and egg are 34.63 , 23.32 lakh tonnes and 73038.9 lakh, respectively, in the year 2011-12 (www.mof, 2014). Per capita availability of animal protein presently stands at around $21 \mathrm{gm}$ meat/day, $43 \mathrm{ml}$ milk/day and $41 \mathrm{egg} / \mathrm{year}$ vis-a-vis the recommended intakes of 120 gm meat/day, $250 \mathrm{ml} \mathrm{milk/day} \mathrm{and} 104$ eggs/year. If $5 \%$ GDP growth is considered then the current production of these commodities need to be increase 2.5 to 3.0 times by the year 2020 to feed the growing population in the country (www. assignmentpapers, 2011). So, Government has given emphasis on researches using livestock investment to produce more livestock production through generated technologies. Though livestock production and productivity have increased due to

*Corresponding author: f.yasmin@barc.gov.bd

Bang. J. Livs. Res. Vol. 20 (1 \& 2), 2013: P. 77-87 ISSN 1022-3851 
modern technologies, it needs more investment in livestock research to face the growing food demand of the people in the country. But investment on livestock research in Bangladesh is inadequate amount. The government is, therefore, urged to raise the investment. The increased investment will certainly encourage scientists to develop technologies to cope with the hazards of climate change and disseminate the same at farmers' level. To support their investments in livestock research, the impact analyses are required by governments and donor agencies.

Impact studies give information to researchers for research program and technology design. The analysis of an impact can also be done at various levels (where applicable) like Individuals or groups (by gender, age, resource endowments), Farm household level (Intra-household), Village level, Regional (province/state/agroecological zone) level, National level and International/World. These are issues that need to be brought to the attention of researchers, research managers, and policy makers. Nagy and Alam (2000) made a study on 'The Impact of Agricultural Research in Bangladesh'. An ex-ante analysis was carried out on the development of the Peste des Petits Ruminants (PPR) vaccine. Yasmin and Alam (2011) assessed the economic and social impact of agricultural research investment. In this study, generated 11 livestock technologies of BLRI were compiled to determine the returns to investment. It showed positive economicimpact on production, employment and income generation. Training and leaflets received, field day and demonstration etc. showed positive social-impact like the gain of knowledge. Impact study of research investment on national economy is very scanty needs to analyze on the basis of structural change approach. With this view in mind, the present study has been proposed to assess the impact of livestock research generated technologies on the GDP of livestock in Bangladesh.

\section{Material and Methods}

\section{Model specification of Structural Change Approach}

Livestock research investment, Livestock modern technology and Livestock GDP are interrelated (Fig.1).

\section{i) Research investment}

Figure 1, shows research investment for BLRI is very important in determining country's livestock GDP. Total investment includes salary and allowances, overhead cost, research and other costs. Research investment is a part of total investment Livestock research depends on the total investment. Earlier there was little budget for livestock research in Bangladesh. Anyway, now a day budget of livestock research is available and is very important in generating livestock technologies. There are two budget sources of livestock research; one is revenue budget and another is development budget but both sources are in small amount in case of livestock research. 
These are as follows:

Revenue Budget: Money that are allocated from government own earning and spend for payment of salary and allowances of government officers, staff and others.

Development Budget: Money is spent for performing development activities in the country which is received by the Government from both internal and external sources.

\section{ii) Modern Technology}

Livestock research includes research on livestock that generates technologies on livestock. A series of data of livestock products contained a structural break to the economy due to a change in livestock technology development. To attain food self-sufficiency, the government of Bangladesh has given special emphasis not only for crops but also for livestock production through expansion of generated livestock technology. However, expansion of technology has taken place in the case of livestock due to dramatic increase in productivity. Almost 59 technologies have been generated (Tech. Manual, 2008). Before the generation of livestock technologies, livestock production was lower. As a result, the GDP of livestock has been affected. GDP increases with the enhancing production of livestock, implies livestock technologies have greater influence on the livestock GDP in Bangladesh.

\section{iii) GDP in Livestock}

Livestock consumption increases day by day. Rising population encourage demand for more livestock products. In this situation, more investment for research generates technologies and technologies enhance production implies increase of more GDP. Fig.1 shows livestock GDP depends on livestock production.

It's true that the production of livestock products increases GDP due to increase the number of livestock population, but livestock products also can be increased by increasing productivity; applying more technologies, for an example, beef fattening. Consequently, demand for investment for livestock research increases. Actually to increase the livestock GDP needs to increase the production of livestock. Though different factors are responsible for GDP preference but research investment is one of them that need to increase. Not only that, a huge number of livestock investment is needed for higher livestock GDP growth but also research investment, modern technology and GDP of livestock are interrelated to find out impact of livestock technologies and needs to estimate GDP performance before and after livestock technology generation. On this background annual growth for both research and GDP of livestock is estimated under Structural Change Approach. To find out the impact, Chow Test has been estimated.

\section{Analytical Framework: Chow Test for Structural Stability / Impact Analysis}

A series of data can often contain a structural break, due to a change in policy or sudden shock to the economy, i.e. technology developed. In order to test for a structural 


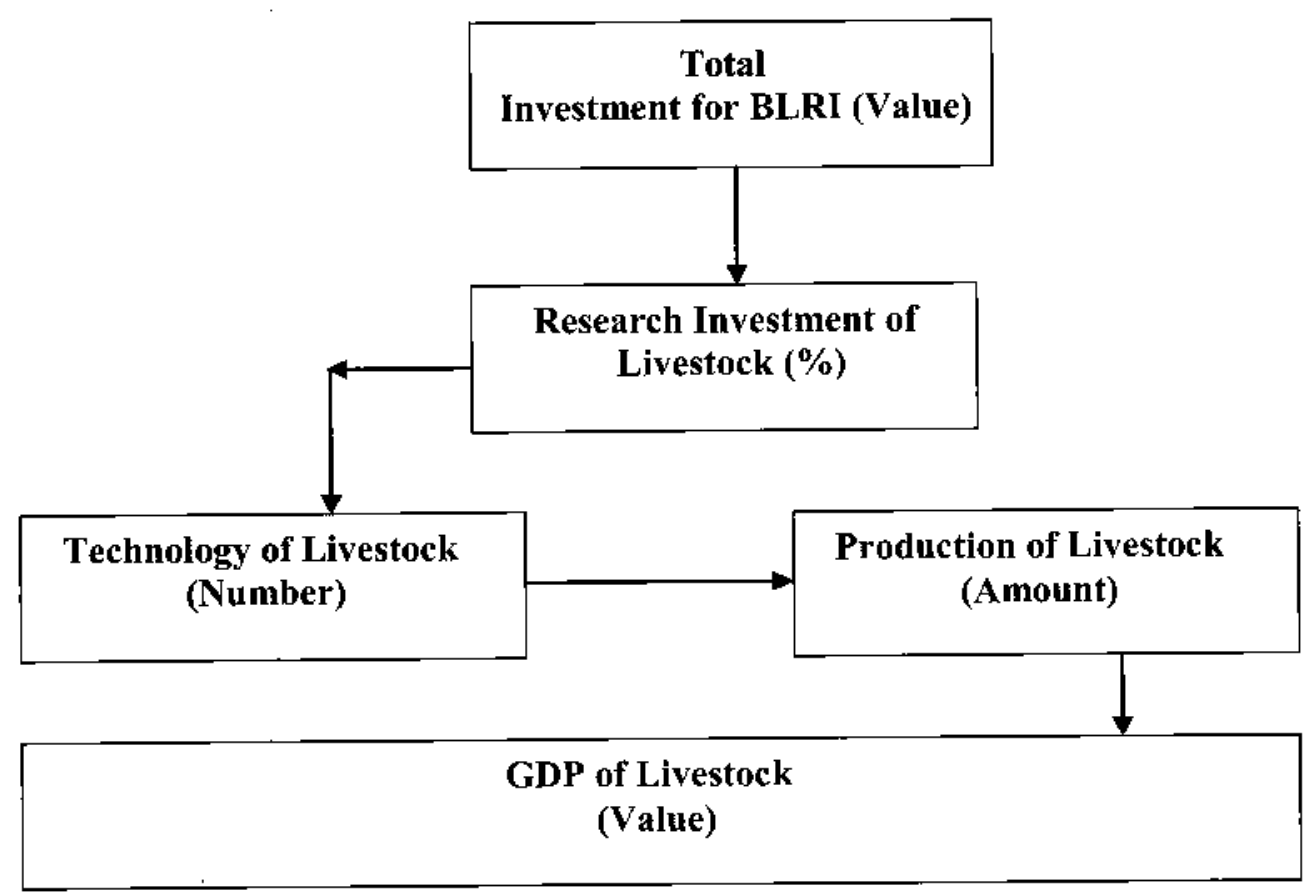

Figure-1. Flow chart of 'GDP' of Livestock in Bangladesh

break, the researchers often use the Chow test, this is Chow' first test. The model in effect uses an F-test to determine whether a single regression is more efficient than two separate regressions involving splitting the data into two sub-samples. This could occur as follows, where in the second case we have a structural break at $t$.

In the first case, we have just a single regression line to fit the data points (scatter plot), it can be expressed as:

$$
y_{t}=\alpha_{0}+\alpha_{1} x_{t}+u_{t}
$$

In the second case, where there is a structural break, we have two separate models, expressed as:

$$
\begin{aligned}
& y_{t}=\beta_{1}+\beta_{2} x_{t}+u_{1 t} \\
& y_{t}=\delta_{1}+\delta_{2} x_{t}+u_{2 t}
\end{aligned}
$$

This suggests that model 1 applies before the break at time t, then model 2 applies after the structural break. If the parameters in the above models are the same, i.e. $\beta_{1}=\delta_{1}, \beta_{2}=\delta_{2}$ , then models 1 and 2 can be expressed as a single model as in case 1 , where there is a single regression line. The Chow test basically tests whether the single regression line or the two separate regression lines fit the data best.

The stages in running the Chow test are:

- Firstly, run the regression using all the data, before and after the structural break, collect RSS . $_{\text {. }}$

- Run two separate regressions on the data before and after the structural break, collecting the RSS in both cases, giving $\mathrm{RSS}_{1}$ and $\mathrm{RSS}_{2}$. 


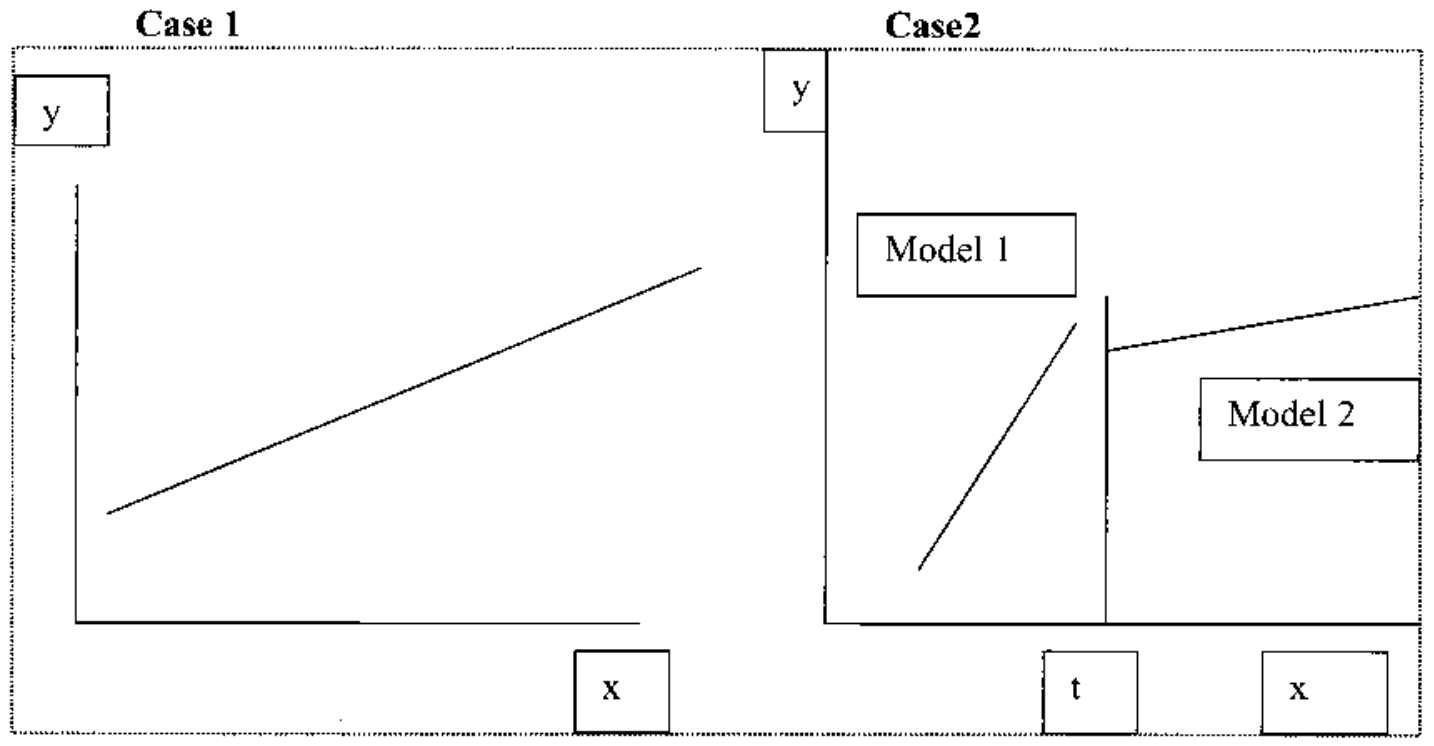

Figure-2. Structural Change

- Using these three values, calculate the test statistic from the following formula:

$$
F-\frac{R S S_{c}-\left(R S S_{1}+R S S_{2}\right) / k}{R S S_{1}+R S S_{2} / n-2 k}
$$

- Find the critical values in the F-test tables, in this case it has $\mathrm{F}(\mathrm{k}, \mathrm{n}-2 \mathrm{k})$ degrees of freedom.

- Conclude, the null hypothesis is that there is no structural break.

Chow test is used to find out whether there is a structural change (Gregory 1960). The assumptions underlying the Chow test are two-folds:

(a) ult- $n(0,2)$ and $u 2 t \mathrm{~N}(0,2)$ that is, the two error terms are normally distributed with the same (homoscedastic) variance 2 and (b) $u 1 t$ and $\mathrm{u} 2 \mathrm{t}$ are independently distributed. The test can test whether there is structural stability of the regression model (Gujrati, 1995).

\section{Estimated Procedure}

\section{Statistical analysis}

The following methods are used to find out the trend and growth rate.

The formula for a linear trend line in a time series analysis is

$$
\mathrm{Ye}=\mathrm{a}+\mathrm{bX}
$$

Where,

$$
\begin{aligned}
& Y e=\text { Dependent variable, } \\
& a=\text { Intercept, } \\
& X=\text { Independent variable, } \\
& b=\text { Growth rate }
\end{aligned}
$$

\section{Growth rates of Research investment}

A simple linear trend of the form $Y=a+b x$ has been used to determine the absolute growth rate for the period from 1992/93 $2009 / 10$. In this case, $b$ is the absolute growth rate, which indicates average change 
in research investment and research to total investment and livestock GDP. Here, the regression coefficient $b$ indicates the magnitude of average change (both positive and negative) in research investment of BLRI. Positive trend coefficients indicate that research investment and research to total investment were time dependent with upward trend. On the other hand, negative trend coefficients indicate that research investment and research to total investment were time dependent with downward trend. Linear equation were fitted to the positive sign of the estimated trend coefficient (b) in all cases indicate a rising trend and negative sign indicate a downward trend.

\section{Hypothesis testing}

There are four main categories of dependent variables in the study. The hypotheses to be tested are as follows:

Investment

- The investment of livestock research is hypothesized as having no relationships with the time and

- The investment of livestock research to total investment is hypothesized as having no relationships with the time.

GDP (livestock)

- The GDP from livestock sector is hypothesized as having no relationships with the time, and

- There is no impact of research investment of livestock research on livestock GDP.

\section{Evaluation Procedure}

The $t$ test was used to test null hypothesis. To estimate the three partial regression coefficients, three restrictions were put on the residual sum of squares (RSS). Following this logic in the four -variable cases, there will be $\mathrm{n}-4 \mathrm{df}$, and so on. Therefore, the $t$ distribution can be used to establish confidence intervals as well as test statistical hypotheses about the true population partial regression coefficients (Gujrati, 1995).

\section{E-views software}

The data were analyzed using the computer E-views software. To apply Chow's breakpoint test, push view/stability tests Chow breakpoint test. On the equation tool-bar, in the dialog box, should list the dates or observation numbers of the breakpoints. For example, if original equation was estimated from 1950 to 1994 , typing 1960 in the dialog specifies two sub-samples, one from 1950 to 1959 and one from 1960 to 1994. Typing 19601970 specifies three sub-samples, 1950 to 1959 , 1960 to 1969 , and 1970 to 1994 (David, 1995).

\section{Empirical Framework}

\section{Source of Data:}

Investment data from 1992-93 to 2009-10 were collected from BLRI. Livestock data has been collected only from BLRI. Data on livestock GDP from $1973 / 74$ to $2009 / 10$ were collected from varous issues of Bangladesh Bureau of Statistics.

\section{E-views software}

Original equation was estimated from 1973 to 2010 , typing 1992 in the dialog specifies two sub-samples, one from typing-specifies two sub-samples, 1973 to 1991 and another one from 1992 to 2010. 


\section{Results and Discussion}

\section{Investment trend for livestock research for generating livestock technologies}

In Table 1, total investment for livestock was increased from Tk. 14.43 in $1992-93$ to 188.92 million in 2009-10, which was on an average, Tk. million 102.24. Total research investment was increased from Tk. 2.99 in 1992-93 to 33.19 , in 2009-10 in the case of BLRI, which was on an average only Tk. million 13.01. Total research investment to total investment for BLRI was $20.72 \%$ in $1992-93$ and $17.37 \%$ in 2009-10. Average was $12.72 \%$.

Trends of research investment (revenue and development budget) to total research investment

In Table 2, research investment under revenue and development budget to total research investment for BLRI has been shown in percentage. It increased from $20.21 \%$ in $1997-98$ to $87.98 \%$ in $2009-10$ whereas decreased from $100 \%$ in 1992-93 to $12 \%$ in 2009-10 in the case of revenue and development budget, respectively. It's indicated government has provided emphasis on livestock research. The average research investment to total research investment for BLRI was $52.57 \%$ from development budget and $41.43 \%$ from revenue budget.

\section{Trends of revenue and development budget for total research investment:}

In Table 2, livestock research investment from revenue and development budget for BLRl has been shown in million Taka.
Livestock research investment under revenue budget for BLRI was increased from Tk. 1.52 million in $1997 / 98$ to $\mathrm{Tk}$. 29.20 million in 2009-10 but-sharply whereas research investment under development budget for BLRI was increased from Tk. 2.99 million in 1992-93 to Tk. 3.99 million in 2009-10 but slowly. From $1992 / 93$ to $1996 / 97$ there was no investment from revenue budget. The average research investment under revenue budget for BLRI was Tk. 7.89 million. The average research investment under development budget for BLRI was Tk. 5.09 million.

\section{Investment growth of livestock research} for generating livestock technologies

Table 3,shows linear trend equation of livestock research investment and livestock research investment to total livestock investment in BLRI. During the period from $1992 / 93$ to $2009 / 10$ BLRI showed growth in terms of livestock research investment in Tk. $1.65 \mathrm{million} / \mathrm{year}$ and Livestock Research to total Livestock Investment in $0.38 \%$ per year. Rising investment in livestock research indicated livestock generated technologies increase livestock production.

Results of "Chow Test" for impact analysis of livestock technology on livestock GDP under Structural Change Approach (1973/74-2009/10). The result shows that the research investment is the main important determinants of the GDP ( Table 4). 
Table 1. Livestock investment in BLRI for generating livestock technologies, 1992- 93 to 2009-2010, Bangladesh, Tk. in million

\begin{tabular}{|c|c|c|c|}
\hline Year & Total investment & Research investment & Research to total investment $(\%)$ \\
\hline $1992-93$ & 14.43 & 2.99 & 20.72 \\
\hline $1992-94$ & 2231 & 2.12 & 9.50 \\
\hline $1994-95$ & 19.11 & 1.81 & 9.47 \\
\hline & 15.40 & 3.50 & 22.73 \\
\hline 1995-96 & 18.24 & 6.50 & 35.06 \\
\hline $1996-97$ & 29.70 & 7.52 & 25.32 \\
\hline $1997-98$ & 187.98 & 8.46 & 4.5 \\
\hline $1998-99$ & 127.17 & 12.15 & 9.55 \\
\hline 1999-00 & 220.83 & 12.50 & 5.66 \\
\hline 2000-01 & 303.17 & 20.64 & 6.81 \\
\hline & 213.50 & 7.75 & 3.63 \\
\hline 2003-04 & 65.99 & 10.95 & 16.59 \\
\hline 2004-05 & 46.51 & 12.81 & 27.54 \\
\hline 2005-06 & 45.33 & 7.76 & 17.12 \\
\hline 2006-07 & 54.02 & 15.65 & 28.97 \\
\hline $2007-08$ & 146.63 & 32.68 & 22.29 \\
\hline 2008-09 & 120.99 & 35.17 & 29.07 \\
\hline 2009-10 & 188.92 & 33.19 & 17.37 \\
\hline Average & 102.24 & 13.01 & 12.72 \\
\hline
\end{tabular}

Source: Yasmin and Alam, 2011 
Table 2. Research investment Tk. in million and investment to total research investment in (\%) of revenue and development budget, BLRI, 1992/93 to 2009-2010.

\begin{tabular}{ccccc}
\hline Year & $\begin{array}{c}\text { Revenue Budget } \\
\text { Total research } \\
\text { investment } \\
\text { Tk. in million }\end{array}$ & $\begin{array}{c}\text { Research investment } \\
\text { to total research } \\
\text { investment (\%) }\end{array}$ & $\begin{array}{c}\text { Development Budget } \\
\text { Total research } \\
\text { investment } \\
\text { Tk. in million }\end{array}$ & $\begin{array}{c}\text { Research investment } \\
\text { to total research } \\
\text { investment (\%) }\end{array}$ \\
\hline $\mathbf{1 9 9 2 - 9 3}$ & 0 & 0 & 2.99 & 100 \\
$\mathbf{1 9 9 2 - 9 4}$ & 0 & 0 & 2.12 & 100 \\
$\mathbf{1 9 9 4 - 9 5}$ & 0 & 0 & 1.81 & 100 \\
$\mathbf{1 9 9 5 - 9 6}$ & 0 & 0 & 3.50 & 100 \\
$\mathbf{1 9 9 6 - 9 7}$ & 0 & 0 & 6.50 & 100 \\
$\mathbf{1 9 9 7 - 9 8}$ & 1.52 & 20.21 & 6.00 & 79.79 \\
$\mathbf{1 9 9 8 - 9 9}$ & .076 & 0.90 & 7.70 & 91.02 \\
$\mathbf{1 9 9 9 - 0 0}$ & 0 & 0 & 12.15 & 0 \\
$\mathbf{2 0 0 0 - 0 1}$ & 4.36 & 34.88 & 8.14 & 65.12 \\
$\mathbf{2 0 0 1 - 0 2}$ & 4.54 & 22 & 16.10 & 78.00 \\
$\mathbf{2 0 0 2 - 0 3}$ & 6.25 & 80.65 & 1.50 & 19.35 \\
$\mathbf{2 0 0 3 - 0 4}$ & 8.65 & 79 & 2.30 & 21 \\
$\mathbf{2 0 0 4 - 0 5}$ & 7.34 & 57.30 & 5.50 & 42.94 \\
$\mathbf{2 0 0 5 - 0 6}$ & 7.75 & 99.87 & 0 & 0 \\
$\mathbf{2 0 0 6 - 0 7}$ & 14.52 & 92.78 & 1.13 & 7.22 \\
$\mathbf{2 0 0 7 - 0 8}$ & 27.85 & 85.22 & 4.83 & 14.78 \\
$\mathbf{2 0 0 8 - 0 9}$ & 29.88 & 84.96 & 5.27 & 14.98 \\
$\mathbf{2 0 0 9 - 1 0}$ & 29.20 & 87.98 & 3.99 & 12.02 \\
$\mathbf{A v e r a g e}$ & $\mathbf{7 . 8 9}$ & $\mathbf{4 1 . 4 3}$ & $\mathbf{5 . 0 9}$ & $\mathbf{5 2 . 5 7}$ \\
\hline $\mathbf{5 0 4 5}$ & & & &
\end{tabular}

Source: Yasmin and Alam, 2011

GDP growth at before/pre-modern technology (1973/74-1991/92)

The growth of livestock GDP was significantly increased by Tk. 130.63 million per year. During pre-modern technology period "(1973/74-1991/92), livestock GDP was increased in small amount due to the production and productivity was lower for the absence of generation of livestock technology. Though people of that period were interested to produce more. At that time no/less investment was generated for livestock research (equation 1). 
Table 3. Linear trend equation of livestock research investment (Tk. million per year) and livestock research investment to total livestock investment (\% per year) for BLRI, 1992/93 to $2009 / 10$

\begin{tabular}{lccc}
\hline Investment & Fitted trend equations & Growth rate (b) & $\mathbf{R}^{2}$ \\
\hline Livestock research investment & $\mathrm{Y}=2.68+1.65 \mathrm{x}$ & 1.65 & 0.68 \\
(Tk. million/year) & $(0.58)(5.85)^{* *}$ & & \\
Livestock research investment to total & $\mathrm{Y}=13.65+0.38 \mathrm{x}$ & 0.38 & 0.54 \\
livestock investment (\% per year) & $(2.82)^{*}(0.86)$ & & \\
\hline
\end{tabular}

The values in parentheses are t-values. * significant at $5 \%$ level and ** significant at $1 \%$ level

\section{GDP growth at after/post-modern technology (1992/93-2009/10)}

The growth of livestock GDP was increased by Tk. 3,044.56 million per year significantly. During Post-modern technology period (1992/93-2009/10) livestock GDP was increased significantly due to the adaption of generated technology such as beef fattening (equation 2).

\section{GDP growth (1973/74-2009/10)}

The results indicate that modem technology has a great impact on livestock GDP. The growth of livestock GDP was increased by Tk. 2665.40 million per year significantly (Equation 3). But GDP responded differently between the period 1973/74-1996/97 (GDP: Tk.130.63 million/year) and 1997/982009/10 (GDP: Tk. 3,044.56 million/year). Furthermore, the result $F$ test of Chow Test $(F 1,35=4.35)$ indicates, growth of livestock GDP is not same at pre and post modern technology period, i. e. technology has great impact on livestock GDP. Result shows that on average research investment was Tk.7.39 million. Increased research investment can save expenditures of livestock products'- import, it means technology has great impact on foreign exchange-savings. It implies the importance of research investment for livestock production.

\section{Conclusion}

There is a structural change in livestock GDP of Bangladesh mainly due to research generating technologies of livestock. Before livestock technology generation, livestock GDP was only Tk. 130.63 whereas after livestock technology generation, livestock GDP was Tk. 3044.56; this means research generating technologies of livestock has positive significant effect on their production, so it is clear that more budget investment mainly needs for livestock research. This study suggests more attention for livestock research to increase livestock technologies implies livestock production and livestock GDP. Therefore, if government gives emphasis for livestock-technology development it would have a great contribution to Bangladesh national economy in future. Further attempt on technology transfer and disseminations is 
Table 4. Co-efficient of Chow test for livestock

\begin{tabular}{|c|c|c|c|}
\hline \multirow[t]{2}{*}{ Coefficients } & Pre-Modern Technology & Post-Modern Technology & Overall \\
\hline & $\begin{array}{c}\text { Period (1973/74-1991/92) } \\
\text { Equation } 1\end{array}$ & $\begin{array}{c}\text { Period (1992/93-2009/10) } \\
\text { Equation } 2\end{array}$ & $\begin{array}{c}\text { Period }(1973 / 74-2009 / 10) \\
\text { Equation } 3\end{array}$ \\
\hline Constant & $\begin{array}{c}-1386.39 \\
(1.58)\end{array}$ & $\begin{array}{c}-19401.58 \\
(-0.58)\end{array}$ & $\begin{array}{l}-10642.10 \\
(-1.93)^{*}\end{array}$ \\
\hline Average & 130.63 & 3044.56 & 2665.40 \\
\hline GDP/Year & $(17.16)^{* *}$ & $(2.66)^{*}$ & $(10.56)^{* *}$ \\
\hline $\mathbf{R}^{2}$ & 0.88 & 0.95 & 0.76 \\
\hline
\end{tabular}

needed to increase the use of livestock technologies for higher livestock production as well as livestock GDP.

\section{References}

BBS, (1975, 1978, 1980, 1982. 1985, 1988, $2000,2010,2005,2008,2013$.). Statistical Year Book of Bangladesh. Bangladesh Bureau of Statistics, Government of the People's Republic of Bangladesh, Dhaka.

David, M.L., Startz, R. Ellsworth, S. and Noh. Engle, J.R. 1995. EViews User Guide (Ist Edn.). QMS Quantitative Micro Software, Irvine, California.p.227.

Gregory C.C. 1960. Test of equality between sets of coefficients in two linear regression, Econometrica, vol, 28. no.3, p.591-605.

Gujrati, D.N. 1995. Econometrics (3rd Edn.). McGraw Hill, New York. P. 239, 243, 263, 269
Internet,www.mof.gov.bd/en/budget/14_15/ ber/en/ch-7(Englash-2014)_Final_Draft. page. 96

Internet,www.assignmentpapers.blogspot.co $\mathrm{m} / 2011 / 10$ /ivestock-and-meat-arketing..

Manual 2008, Livestock and Poultry Technology Manual, Second Edition, Publisher, Bangladesh Livestock Research Institutes, Savar, Dhaka-1341.Bangladesh, June, p.1-310.

Nagy, J.G. and Alam, M.F. 2000. The Impact of Agricultural Research in Bangladesh: Estimating Returns to Agricultural Research. Final Report of Bangladesh Agricultural Research Management Project.: xi, 7-8, and 89-90.

Yasmin, F. and Alam K. 2011, Agricultural research of NARS institutes and Its impact on National Economy". BARC Project Report, 20 July, p.36-44, 85. 